DOI https://doi.org/10.15589/znp2020.1(479).16

УДК 504.3.054:66.074.51

\title{
JUSTIFICATION OF THE EXPEDIENCY OF GAS AND DUST EMISSIONS WET CLEANING AT COAL-MINE BOILER HOUSE
}

\section{ОБГРУНТУВАННЯ ДОЦІЛЬНОСТІ МОКРОЇ ОЧИСТКИ ГАЗОПИЛОВИХ ВИКИДІВ НА ШАХТНІЙ КОТЕЛЬНІ}

\author{
Oleksandr S. Kovrov \\ kovralex1@gmail.com \\ ORCID: 0000-0003-3364-119X \\ Daria V. Kulikova \\ kisaalisa@i.ua \\ ORCID: 0000-0003-0874-0188 \\ Zlata L. Sushko \\ Sushko.Zlata7@gmail.com \\ ORCID: 0000-0003-4083-4598
}

О. С. Ковров,

докт. техн. наук, доцент

Д. В. Кулікова,

канд. техн. наук, доцент

3. Л. Сушко,

студентка

\author{
National Technical University "Dnipro Polytechnic”, Dnipro, \\ Національний технічний університет «Дніпровська політехніка», м. Дніпро
}

\begin{abstract}
Purpose. The purpose of the study is to substantiate the feasibility of gas and dust emissions wet cleaning application at the coal mine boiler room and predictive assessment of the aerosol scrubber efficiency depending on the technological parameters of the gas purification process and the size of dust particles.

Method. The paper deals with the method of calculation of fractional and overall efficiency for aerosol scrubbers proposed by US Environmental Protection Agency that is widely used in American universities and engineering companies. The object of the study is the effectiveness of wet cleaning of dust and gas emissions. The subject of the study is the efficiency of trapping solid dust particles in the aerosol scrubber.

Results. The fractional efficiency of the hollow aerosol scrubber was calculated depending on the technological parameters of the gas purification process and the size of the dust particles for the technological conditions of the industrial boiler room of the coal mine "Ukraina" of the Public Enterprise "Selidivvugillya".

Scientific novelty. It is established that the hollow aerosol scrubber picks up fine particles of dust larger than $5 \mu \mathrm{m}$ in size, and particles of $3 \mu \mathrm{m}$ are critical size for these technological conditions. Dust capture increases with increasing density. Taking into consideration that the dust density is about $\rho_{\mathrm{p}}=1.5 \mathrm{~g} / \mathrm{cm}^{3}$, the particles with size of $5 \mu \mathrm{m}$ are captured with overall efficiency $\eta_{\text {tot }}=99.98 \%$, and for particles $3 \mu \mathrm{m} \eta_{\text {tot }}=88.39 \%$ respectively.

Practical importance. For the technological conditions of the boiler house of coal mine "Ukraina" the sufficient amount of irrigation fluid for satisfactory washing of gases from dust will make $Q_{L} / Q_{G}=11 / \mathrm{m}^{3}$, and the amount of wastewaters will make $Q_{\mathrm{st}}=22,25 \mathrm{~m}^{3} / \mathrm{h}$. Taking into consideration the fractional efficiency of the scrubber, depending on the irrigation fluid flow rate and the particle density, it is assumed that the maximum trapping of fine dust particles is possible for fractions $d_{p} \geq 5 \mu \mathrm{m}$.
\end{abstract}

Key words: gas and dust purification; coal mine boiler room; hollow aerosol scrubber; fractional efficiency.

Анотація. Мета. Мета дослідження полягає в обгрунтуванні доцільності мокрої очистки газопилових викидів на шахтній котельні та прогнозній оцінці ефективності впровадження порожнистого скрубера залежно від технологічних параметрів процесу газоочистки та розміру частинок пилу.

Методика. У статті використано методику розрахунку фракційної й загальної ефективності аерозольних скруберів Агенції з охорони навколишнього середовища США, яка широко використовується в американських університетах та інжинірингових компаніях. Об'єктом дослідження є ефективність мокрої очистки газопилових викидів. Предметом дослідження є ефективність уловлювання твердих часток пилу аерозольним скрубером.

Результати. Виконано розрахунок фракційної ефективності порожнистого аерозольного скрубера залежно від технологічних параметрів процесу газоочистки та розміру частинок пилу для технологічних умов промислової котельні ВП «Шахта «Україна» Державного підприємства «Селидіввугілля».

Наукова новизна. Встановлено, що порожнистий скрубер уловлює дрібнодисперсні частки пилу розміром більше 5 мкм, а частки 3 мкм становлять критичний розмір для таких технологічних умов. Уловлювання пилу зростає зі збільшенням його щільності. 3 огляду на те, що щільність пилу становить близько $\rho_{\mathrm{p}}=1,5$ г/см 


\section{ТЕХНОЛОГІЇ ЗАХИСТУ НАВКОЛИШНЬОГО СЕРЕДОВИЩА № 1 - 2020}

частки розміром 5 мкм уловлюються з ефективністю $\eta_{\text {заг }}=99,98 \%$, а для часток 3 мкм $\eta_{\text {заг }}=88,39 \%$ відповідно. Практична значимість. Для технологічних умов котельні шахти «Україна» достатні витрати зрошувальної рідини для задовільної очистки газів від пилу становитимуть $Q_{L} / Q_{G}=1 \pi / \mathrm{M}^{3}$, а обсяги утворення промивних стічних вод становитимуть $Q_{\text {ст }}=22,25 \mathrm{~m}^{3} /$ год. 3 урахуванням фракційної ефективності скрубера залежно від витрат зрошувальної рідини та щільності часток можна припустити, що максимальне уловлювання дрібнодисперсного пилу можливе для фракцій $d_{p} \geq 5$ мкм.

Ключові слова: очистка газопилових викидів; шахтна котельня; порожнистий аерозольний скрубер; фракційна ефективність.

\section{ПОСТАНОВКА ЗАДАЧІ}

Викиди забруднюючих речовин підприємствами теплоенергетики, зокрема промисловими та комунально-побутовими котельнями, внаслідок згоряння органічного палива $є$ одним з основних джерел забруднення атмосфери у вуглевидобувних регіонах. Обсяги шкідливих газопилових викидів пов'язані 3 якістю і кількістю вугілля, що спалюється, повнотою його використання, а також 3 режимом роботи джерела теплопостачання. Під час спалювання твердого палива, перш за все вугілля, в атмосферу з димовими газами надходить летюча зола, частки якої містять вуглець, двоокис кремнію, оксиди алюмінію і заліза, сірчаний ангідрид, летючі органічні сполуки, важкі метали та інші хімічні елементи [1, с. 52].

Промислові та комунально-побутові котельні, що працюють на вугіллі і розміщуються, як правило, в межах невеликих населених пунктів, становлять велику екологічну небезпеку для біосфери і здоров'я населення. Тому впровадження технологій мокрої очистки викидів твердих та газоподібних домішок від котелень $\epsilon$ актуальним природоохоронним заходом у регіонах, де вугілля $є$ пріоритетним джерелом теплопостачання.

\section{АНАЛІЗ ОСТАННІХ ДОСЛІДЖЕНЬ І ПУБЛІКАЦІЙ}

На діючих шахтах котельні використовують вугілля зольністю понад $23 \%$ та оснащені газоочисним обладнанням, що забезпечує вловлювання летючої золи 3 димових газів. До такого обладнання належать «сухі» циклони типу ЦН-15 і батарейні типу БЦ. Проєктний ступінь очищення циклонів варіює від 80 до $90 \%$, але з часом експлуатації котельні знижується до $70-75 \%[2$, c. 36$]$.

Для зниження викидів, зокрема оксидів азоту, в атмосферу пропонуються технічні вдосконалення конструкції котлів ДКВР-20-13, які часто використовуються у твердопаливних котельнях [3, с. 576]. Це дало змогу авторам принаймні на $30 \%$ зменшити валові викиди оксиду азоту.

Вприскування пари в зону горіння також може знизити викиди оксидів азоту, які вважаються більш токсичними за чадний газ [4, с. 1-8].

Шкідливі викиди оксидів азоту можна також знизити за допомогою модифікації теплових режимів котлоагрегатів [5, с. 5-6]. Залежно від режиму роботи котлів у опалювальний період можна забезпечити зменшення викидів оксидів азоту в навколишне середовище до $60 \%$ за рахунок зниження температури в зоні горіння.

Пропонуються також технології одночасного зниження емісій оксидів азоту $\mathrm{NO}_{x}$ та сірки $\mathrm{SO}_{\text {x }}$ завдяки використанню ацетату магнію та кальцію (АМК) у вигляді пилоподібної маси. Вугілля США та Великобританії зі значно різним вмістом сірки було використано як основне паливо, а АМК суміш вводили у вигляді розчину в гази згоряння горизонтально протилежними двофазними розпилювачами за температури $1100-1200^{\circ} \mathrm{C}$. Зниження $\mathrm{SO}_{2}$ становило $70-80 \%$, а $\mathrm{NO}_{\text {x }}$ - від 30 до $50 \%$ відповідно залежно від параметрів процесу очистки [6, с. 149-155].

\section{ВІДОКРЕМЛЕННЯ НЕ ВИРІШЕНИХ РАНІШЕ ЧАСТИН ЗАГАЛЬНОЇ ПРОБЛЕМИ}

Для уловлювання твердих часток пилу, а також газоподібних водорозчинних оксидів азоту $\mathrm{NO}_{\text {x }}$ та сірки $\mathrm{SO}_{\mathrm{x}}$ можна використовувати мокрі апарати газоочистки. Зазвичай мокрі апарати використовуються обмежено через головний їх недолік стосовно утворення рідких відходів у процесі експлуатації.

Проте пиловловлювачі мокрого очищення повітря від пилу, особливо дрібнодисперсного з розмірами часток 0,5-10 мкм, набули значного поширення на промислових підприємствах. Висока ефективність очищення газів досягається в тому разі, якщо промивна рідина розпилюється через форсунки з утворенням крапель 0,5-1 мм [7, стор. 256-270].

У роботі пропонується оцінити доцільність упровадження порожнистих скруберів в умовах шахтної котельні для уловлювання як твердих часток золи, а також водорозчинних газоподібних сполук, що дасть змогу значно знизити валові викиди в атмосферу та знизити рівень екологічної небезпеки у вуглевидобувних регіонах України.

Мета дослідження полягає в обгрунтуванні доцільності мокрої очистки газопилових викидів на шахтній котельні.

Для досягнення поставленої мети вирішено такі завдання:

1) виконано розрахунок фракційної ефективності порожнистого аерозольного скрубера залежно від технологічних параметрів процесу газоочистки та розміру частинок пилу;

2) виконано прогнозну оцінку ефективності впровадження порожнистого скрубера в технологію 
очистки димових газів шахтної котельні залежно від витрат зрошувальної рідини та щільності часток пилу.

\section{МЕТОДИ, ОБ'ЄКТ ТА ПРЕДМЕТ ДОСЛІДЖЕННЯ}

Під час дослідження були використані такі наукові методи:

- метод аналізу інформаційних джерел стосовно використання апаратів та устаткування мокрої очистки газів у теплоенергетиці;

- методика розрахунку фракційної і загальної ефективності аерозольного скрубера Агенції з охорони навколишнього середовища США (https://www. epa.gov), яка широко використовується в американських університетах та інжинірингових компаніях.

Об'єктом дослідження є ефективність мокрої очистки газопилових викидів. Предметом дослідження $є$ ефективність уловлювання твердих часток пилу аерозольним скрубером.

\section{ОСНОВНИЙ МАТЕРІАЛ}

Доцільність застосування мокрої газоочистки на шахтних котельнях

Пиловловлювачі мокрого очищення працюють за принципом осідання частинок пилу на поверхню крапель. Для зниження виносу крапель рідини швидкість газу в апараті не повинна перевищувати $1-1,2 \mathrm{~m} / \mathrm{c}$. Витрати води становлять $5-10 \mathrm{~m}^{3} /$ год на $1 \mathrm{~m}^{2}$ площі поперечного перерізу. Найбільш повно в цих апаратах уловлюються частинки пилу більше 10 мкм. Сфера застосування мокрих пиловловлювачів поширюється на машинобудівні, ливарні, гірничі, металургійні, нафтодобувні, деревообробні та інші підприємства [7, с. 256-270].

Впровадження мокрої очистки на промислових котельнях, які використовують енергетичне вугілля, $€$ досить перспективним через низьку якість вихідного палива, значні викиди твердих та газоподібних речовин та надмірне забруднення приземного шару атмосфери.

Такий природоохоронний захід є доцільним для технології теплопостачання на відокремленому підрозділі «Шахта «Україна» Державного підприємства «Селидіввугілля» (м. Українськ Донецької обл.), що введена в експлуатацію у 1963 році з потужністю 1200 тис. тонн вугілля на рік. На одному проммайданчику спільно з ВП «Шахта «Україна» розміщується центральна збагачувальна фабрика «Україна» ДП «Селидіввугілля».

Вугілля шахти «Україна» внаслідок низької спікливості і високої сірчистості після збагачення використовується виключно для енергетичних цілей. Як паливо в котельні використовується вугільний концентрат марки «Д-промпродукт» 3 ЦЗФ «Україна» ДП «Селидіввугілля» та рядове вугілля марки «Д» 3 шахти. Споживачами тепла є системи опалення, вентиляції, гарячого водопостачання та технологічного теплопостачання адміністративно-побутового комбінату.

Згідно з проєктом шахти середньорічні показники якості вугілля такі: зольність на суху масу - 30-38\%, сірчистість - 3,16\%, вологість - 10,0-11,0\%.

Наявна шахтна котельня виробляє 16 Гкал/год те-

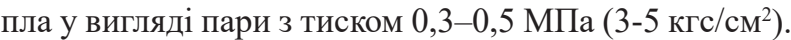
У котельні встановлено 4 котли типу ДКВР-6,5/13 3 топками ПМ-ЗРПК. Витрати вугілля такі: максимальна годинна 8674 кг/год, 15,6 тис. т/рік.

Для очищення відпрацьованих димових газів використовуються золоуловлювачі типу БЦ (батарейні циклони) з ефективністю 80-86\% для зниження викидів твердих часток пилу. Після часткового очищення димові гази викидаються в атмосферу через цегляну димову трубу висотою 45 м і діаметром гирла 1500 мм. Викиди забруднюючих речовин в атмосферу від промислової котельні шахти «Україна» наведено в табл. 1.

ВП «Шахта «Україна» належить до 2 класу екологічної небезпеки із санітарно-захисною зоною (С33), що дорівнює 500 м. Згідно з уточнюючими розрахунками стосовно вмісту та розсіювання забруднюючих речовин у приземному шарі атмосфери С33 становить: у північному напрямку 500 м, у східному - 480 м, у південному - 940 м, південно-західному - 1550 м. У межах санітарнозахисної зони шахти знаходиться житлова забудова в кількості 28 одноповерхових, 39 двоповерхових і 2 п’ятиповерхових будинків.

Таблиця 1. Викиди забруднюючих речовин від шахтної котельні

\begin{tabular}{|c|c|c|c|c|}
\hline $\begin{array}{c}\text { Найменування } \\
\text { забруднюючих } \\
\text { речовин }\end{array}$ & \multicolumn{2}{|c|}{ ГДВ } & \multicolumn{2}{|c|}{$\begin{array}{c}\text { Фактичні викиди } \\
\text { забруднюючих } \\
\text { речовин }\end{array}$} \\
\cline { 2 - 5 } & г/с & т/рік & г/с & т/рік \\
\hline $\begin{array}{c}\text { Пил 3 } \mathrm{SiO}_{2} \\
\text { (20-70\%) }\end{array}$ & 19,6 & 56,89 & 9,4 & 31,878 \\
\hline Сірчистий ангідрид & 11,9 & 356,1 & 9,7 & 243 \\
\hline Окис вуглецю & 11,54 & 34,25 & 41,4 & 49,66 \\
\hline Оксиди азоту & 5,43 & 18,11 & 8,5 & 23,355 \\
\hline
\end{tabular}

3 огляду на вищевикладене запровадження мокрої газоочистки на шахтній котельні $є$ доцільним природоохоронним заходом, який дасть змогу суттєво зменшити викиди в атмосферне повітря відповідно до вимог СЗ3.

Розрахунок аерозольного скрубера за методикою Агенції з охорони навколишнього середовища CШIA

В аерозольних скруберах запилені гази пропускають через завісу зрошувальної рідини. При цьому частинки пилу захоплюються краплинами промивної рідини й осаджуються в скрубері, а очищені гази видаляються з апарата. У порожнистому скрубері 
(рис. 1) краплини 3 форсунок подають назустріч запиленому потоку газів. Вони повинні бути настільки великими, щоб не виносились газовим потоком, швидкість якого становить від 0,2 до 1,2 м/с. У разі перевищеної зазначеної межі після газопромивника необхідно встановлювати краплевловлювач [8, с. 94].

Для розрахунку порожнистих скруберів пропонуються різні рівняння, які пов'язують значення загальної ефективності уловлювання часток пилу зі значеннями окремих факторів, що впливають на роботу цих апаратів [9, с. 317-329].

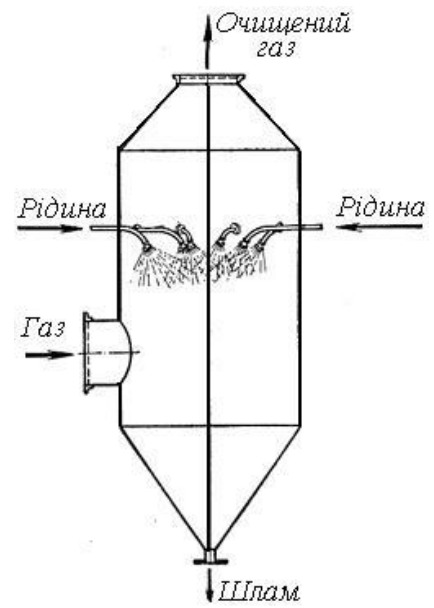

Рис. 1. Схема будови й роботи вертикального аерозольного скрубера

У цій статті представлено методику розрахунку порожнистих скруберів за методикою Агенції з охорони навколишнього середовища США (https://www. epa.gov), яка широко використовується в американських університетах та інжинірингових компаніях [10, с. 209-222].

За цією методикою вміст пилу у викиді після очищення в аерозольному скрубері (від 0 до 1) обчислюється за такою формулою:

$$
P t_{d}=\exp \left(-\frac{3 Q_{L} V_{t d} z \eta_{d}}{4 Q_{G} r_{d}\left(V_{t d}-V_{G}\right)}\right)=\exp \left(-\frac{A_{d} V_{t d} \eta_{d}}{Q_{G}}\right) \%,(1)
$$

де $Q_{L}$ - об'ємна витрата рідини, $\mathbf{m}^{3} / \mathrm{c} ; \mathrm{Q}_{G}-$ об'ємна витрата газу, м³/c; $V_{G}$ - поверхнева швидкість переміщення газу, см/c; $V_{t d}-$ кінцева швидкість осадження крапель рідини, см/с (визначається за номограмами осадження частинок залежно від їх щільності та діаметра, рис. 2); $\eta_{\mathrm{d}}$ - ефективність уловлювання окремої фракції пилу (від 0 до 1); $r_{\mathrm{d}}$ - радіус крапель, см; $z$ - довжина контактної зони в скрубері,

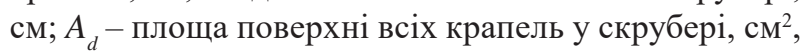
яку визначають за такою формулою:

$$
A_{d}=\frac{3 Q_{L} z}{4 r_{d}\left(V_{t d}-V_{G}\right)} .
$$

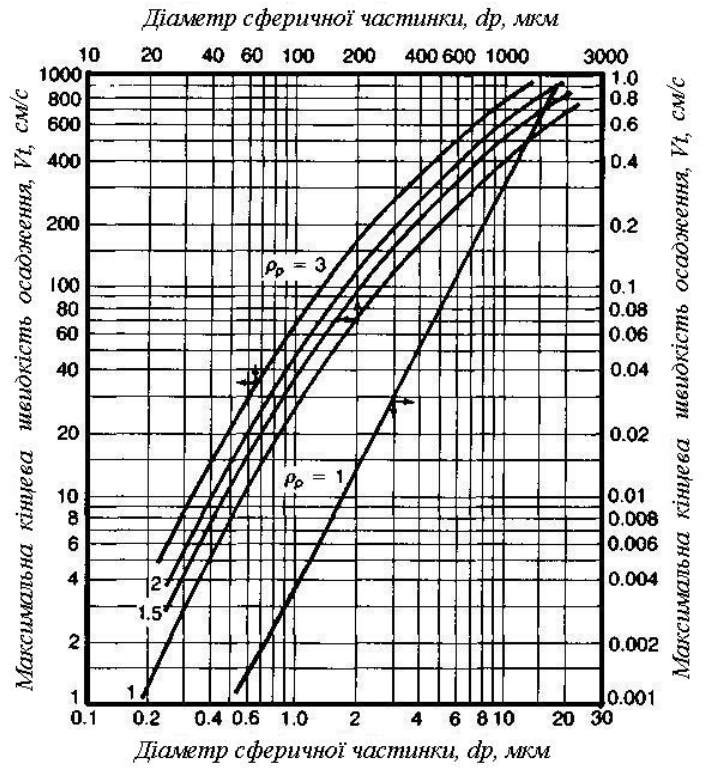

Рис. 2. Значення максимальної швидкості осадження частинок [10]

Фракційну ефективність уловлювання розраховують таким чином:

$$
\eta_{d}=\left(\frac{K_{p}}{K_{p}+0,7}\right)^{2}
$$

Коефіцієнт $K_{p}$, що враховує ефект інерційного зіткнення частинок пилу з краплями рідини, обчислюють за таким співвідношенням:

$$
K_{p}=\frac{C \rho_{p} d_{p}^{2} V_{p, d}}{9 \mu_{G} d_{d}}=\frac{\rho_{w} d_{a}^{2} V_{p, d}}{9 \mu_{G} d_{d}},
$$

де $C$ - поправковий коефіцієнт Каннінгема, безрозмірний (рис. 3); $\rho_{p}$ - щільність частинок, г $/ \mathrm{cm}^{3} ; \mathrm{d}_{p}-$ фізичний діаметр частинок, $\mathrm{cm} ; \mathrm{V}_{p, d}-$ швидкість руху частинок (стосовно крапель), см/c; $d_{d}^{p, d}-$ діаметр крапель, см; $\mu_{G}-$ опір газового середовища, г/см·c (табл. 2); $d_{a}-$ аеродина-

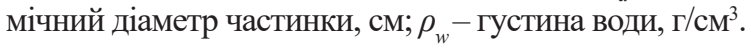

Таблиця 2. Значення в’язкості повітря залежно від температури

\begin{tabular}{|c|c|c|}
\hline \multirow{2}{*}{ Температура, $\boldsymbol{t},{ }^{\circ} \mathbf{C}$} & \multicolumn{2}{|c|}{ В'язкість $\boldsymbol{\mu}$} \\
\cline { 2 - 3 } & кг/м•год & $\boldsymbol{\Gamma} / \mathbf{c м} \cdot \mathbf{c}$ \\
\hline 10 & 0,064 & 0,000178 \\
\hline 20 & 0,065 & 0,000181 \\
\hline 30 & 0,067 & 0,000186 \\
\hline 40 & 0,070 & 0,000194 \\
\hline 50 & 0,071 & 0,000198 \\
\hline 60 & 0,071 & 0,000198 \\
\hline 70 & 0,074 & 0,000207 \\
\hline 80 & 0,076 & 0,000211 \\
\hline 90 & 0,077 & 0,000215 \\
\hline 100 & 0,079 & 0,000219 \\
\hline
\end{tabular}


Для частинок пилу, фізичний розмір яких $d_{p} \geq 10$ мкм, поправковий коефіцієнт Каннінгема дорівнює 1.

Аеродинамічний діаметр частинки $d_{a}$ визначається як діаметр сфери, що має таку саму швидкість осадження, як і фізична частинка, щільність якої $\rho_{p}=$ $\rho_{\mathrm{w}}=1000 \kappa \Gamma / \mathrm{M}^{3}$, та розраховується за такою формулою:

$$
d_{a}=\sqrt{\frac{18 \mu v_{t}}{C \rho_{w} g}} \mathrm{M}
$$

де $\mu$ - в'язкість газу, кг/м'с; $v_{\mathrm{t}}$ - гранична швидкість осідання частинки, м/c; $\rho_{\mathrm{w}}-$ густина води, кг $/ \mathrm{M}^{3}$; $g$ - гравітаційне прискорення, г/ $\mathrm{c}^{2}$.

У вертикальних скруберах швидкість руху частинок пилу стосовно крапель відповідає кінцевій швидкості осадження крапель рідини, тобто $\mathrm{V}_{p, d}=V_{t, d}$ [10, с. 209-222].

Якщо загальна ефективність скрубера $\eta_{\text {заг }}$ розраховується як сума значень ефективності вловлювання частинок різних фракцій, то її обчислюють за такою формулою:

$$
\eta_{\text {заг }}=\sum_{j=1}^{n} \eta_{j} \cdot m_{j}, \%
$$

де $\eta_{j}$ - ефективність уловлювання частинок $j$-ï фракції, $\mathrm{m}_{j}$ - масовий вміст частинок $j$-ї фракції, \%.

Відповідно, загальний викид в атмосферу часток пилу $P$ розраховується за формулою:

$$
P=100-\eta_{\text {заг }}, \% \text {. }
$$

Прогнозна оцінка ефективності впровадження порожнистого скрубера в технологію очистки димових газів шахтної котельні

Пилові частинки золи, що потрапляють в атмосферу внаслідок спалювання вугілля в котлоагрегатах котельні, становлять певну екологічну проблему залежно від їх розміру та фракційного розподілу. Одиночні та батарейні циклони, що зазвичай використо- вуються на котельнях, є неефективними для вловлювання дрібнодисперсних часток пилу розмірами менше 10 мкм, частинки пилу менше 5 мкм практично не вловлюються. Проте саме дрібнодисперсний пил спроможний переноситись на далекі відстані за межі C33 та становити небезпеку для довкілля та здоров'я населення.

Тому прогнозна оцінка впровадження порожнистого скрубера в технологію очистки димових газів шахтної котельні є доцільною.

Згідно із запропонованою вище методикою виконано розрахунки вмісту фракції пилу розміром 5 мкм у викидах після очищення у вертикальному скрубері за таких технологічних умов: $Q, / Q_{G}=1 л / \mathrm{m}^{3}$ або $0,001 \mathrm{~m}^{3} / \mathrm{M}^{3}$; поверхнева швидкість газу $\mathrm{V}_{G}=20 \mathrm{~cm} / \mathrm{c} ; d_{d}=300$ мкм; $z=300 \mathrm{~cm} ; T=90{ }^{\circ} \mathrm{C} ; V_{\mathrm{td}}=120 \mathrm{~cm} / \mathrm{c}$ (рис. 2); $\mu_{G}=$ 0,074 кг/м·год $=0,000206$ г/см'с; $\rho_{p}=1,5 \Gamma / \mathrm{cm}^{3}$.

1. Визначаємо аеродинамічний діаметр частинок $\mathrm{d}_{a}$ таким чином:

$$
\begin{aligned}
& d_{a}=\sqrt{\frac{18 \mu v_{t}}{C \rho_{w} g}}=\sqrt{\frac{18 \cdot 0,074 \mathrm{Kг} / \mathrm{M} \cdot \text { год } \cdot 0,3 \mathrm{~cm} / \mathrm{c} \cdot 0,01 \mathrm{~cm} / \mathrm{M}}{3600 \mathrm{c} / \text { год } \cdot 1,033 \cdot 1000 \mathrm{Kг} / \mathrm{M}^{3} \cdot 9,81 \mathrm{M} / \mathrm{c}^{2}}}=\sqrt{\frac{0,003996}{36481428}}= \\
& \sqrt{1,095 \mathrm{e}^{-10}}=1,047 \cdot 10^{-5} \mathrm{M}=10,47 \text { мкм. }
\end{aligned}
$$

2. Обчислюємо значення коефіцієнта $K_{p}$, тобто $K_{p}=\frac{C \rho_{\rho} d_{p}^{2} V_{p, d}}{9 \mu_{G} d_{d}}=\frac{1,033 \cdot 1,5 \mathrm{r} / \mathrm{cm}^{3} \cdot(0,0005 \mathrm{~cm})^{2}(120 \mathrm{~cm} / \mathrm{c})}{9,0 \cdot(0,000206 \text { г } / \mathrm{cm} \cdot \mathrm{c})(0,030 \mathrm{~cm})}=\frac{0,000046485}{0,00005562}=0,84$.

3. Визначаємо фракційну ефективність скрубера, a саме:

$$
\eta_{d}=\left(\frac{K_{p}}{K_{p}+0,7}\right)^{2}=\left(\frac{0,84}{0,84+0,7}\right)^{2}=0,298, \text { тобто } 29,8 \% .
$$

4. Розраховуємо вміст частинок пилу у викиді таким чином:

$$
\begin{aligned}
& P t_{d}=\exp \left(-\frac{3 Q_{L} V_{t d} z \eta_{d}}{4 Q_{G} r_{d}\left(V_{t d}-V_{G}\right)}\right)=\exp \left(-\frac{3(0,001)(120)(300)(0,298)}{4(0,015)(120-20)}\right)= \\
& =2,718^{\left(-\frac{-32,132}{6}\right)}=2,718^{(-5.355)}=0,00473 \text { або } 0,47 \% .
\end{aligned}
$$

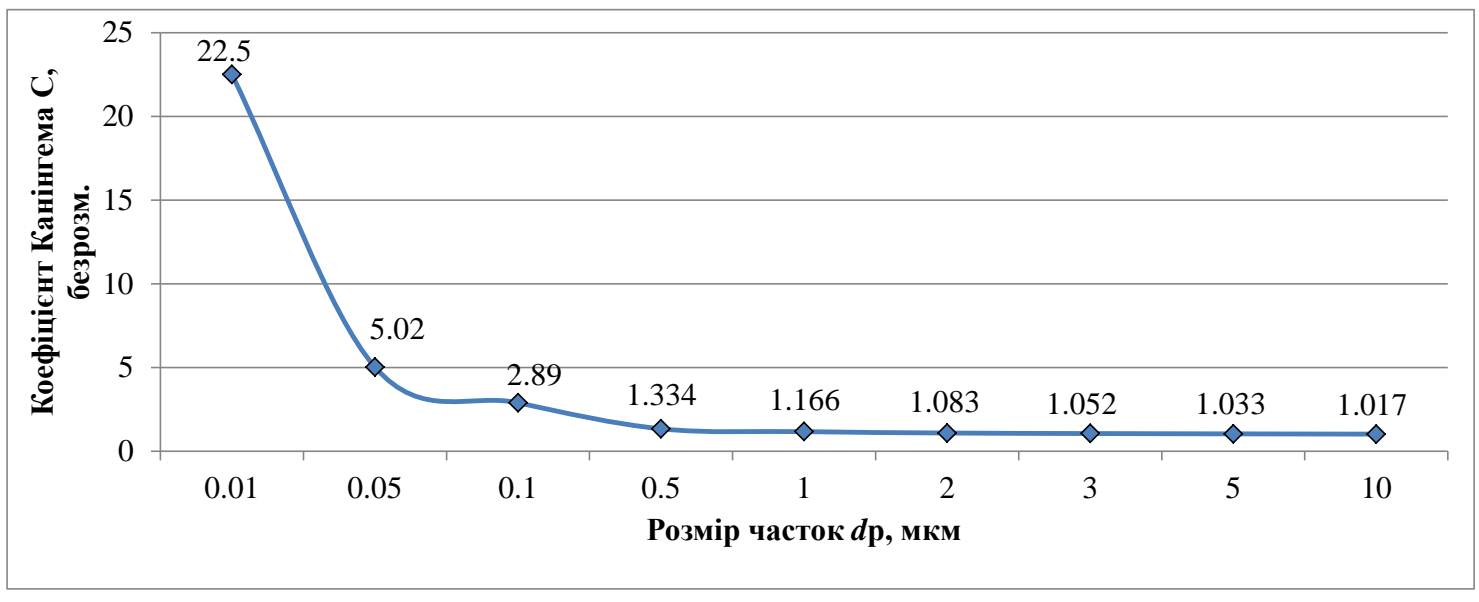

Рис. 3. Залежність коефіцієнта Каннінгема $C$ від розміру часток пилу $\mathrm{d}_{p}$ 


\section{ТЕХНОЛОГІЇ ЗАХИСТУ НАВКОЛИШНЬОГО СЕРЕДОВИЩА № 1 2020}

Отже, ефективність уловлювання частинок пилу діаметром 5 мкм становить 99,53\%.

На рис. 4 представлено результати розрахунків фракційної ефективності вертикального порожнистого скрубера залежно від кількості зрошення. Цей параметр є впливовим, тому що пов'язаний як з ефективністю зрошення газів, так і з обсягом утворення промивних стічних вод. Виконані розрахунки дають змогу зробити висновок, що порожнистий скрубер вловлює дрібнодисперсні частки пилу розміром більше 5 мкм, а частки 3 мкм становлять критичний розмір для таких технологічних умов.

На рис. 5 представлено результати розрахунків фракційної ефективності скрубера залежно від щільності часток, з чого витікає, що уловлювання пилу зростає із щільністю пилу. 3 огляду на те, що щільність пилу становить близько $\rho_{\mathrm{p}}=1,5$ г $/ \mathrm{cm}^{3}$, частки розміром 5 мкм уловлюються з ефективністю $\eta_{\text {заг }}=99,98 \%$, а для часток 3 мкм $\eta_{\text {заг }}=88,39 \%$ відповідно для таких технологічних умов.

\section{ОБГОВОРЕННЯ ОТРИМАНИХ РЕЗУЛЬТАТІВ}

Аналізуючи рис. 4, можна припустити, що доцільні витрати зрошувальної рідини можуть коливатись у межах $\mathrm{Q}_{\mathrm{L}} / \mathrm{Q}_{G}=1 \ldots 5$ л/ $\mathrm{M}^{3}$.

Зазвичай питомі витрати зрошувальної рідини

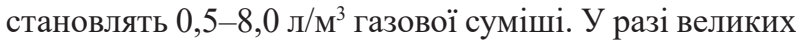
концентрацій пилу на вході в скрубер (10-12 г/м³) цей параметр становить 6,0-8,0 л/м³ [9, с. 326].

Для технологічних умов котельні шахти «Україна» усереднений обсяг технологічних газів $\mathrm{V}_{\text {г }}$ становить:

$\mathrm{V}_{\mathrm{r}}=S \cdot v=\pi \mathrm{D}^{2} / 4 \cdot v=\left(3,14 \cdot(1,5)^{2} / 4\right) \cdot 3,5 \mathrm{M} / \mathrm{c}=6,18 \mathrm{~m}^{3} / \mathrm{c}$.

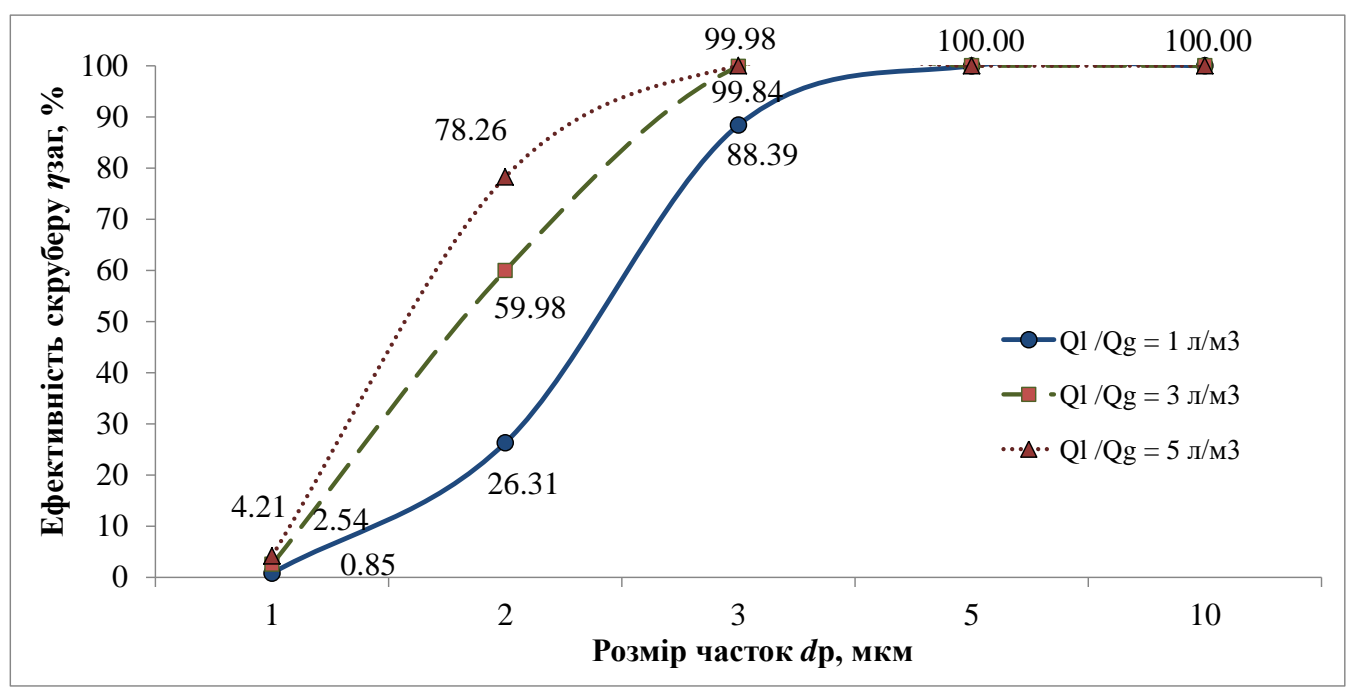

Рис. 4. Фракційна ефективність скрубера залежно від кількості зрошення

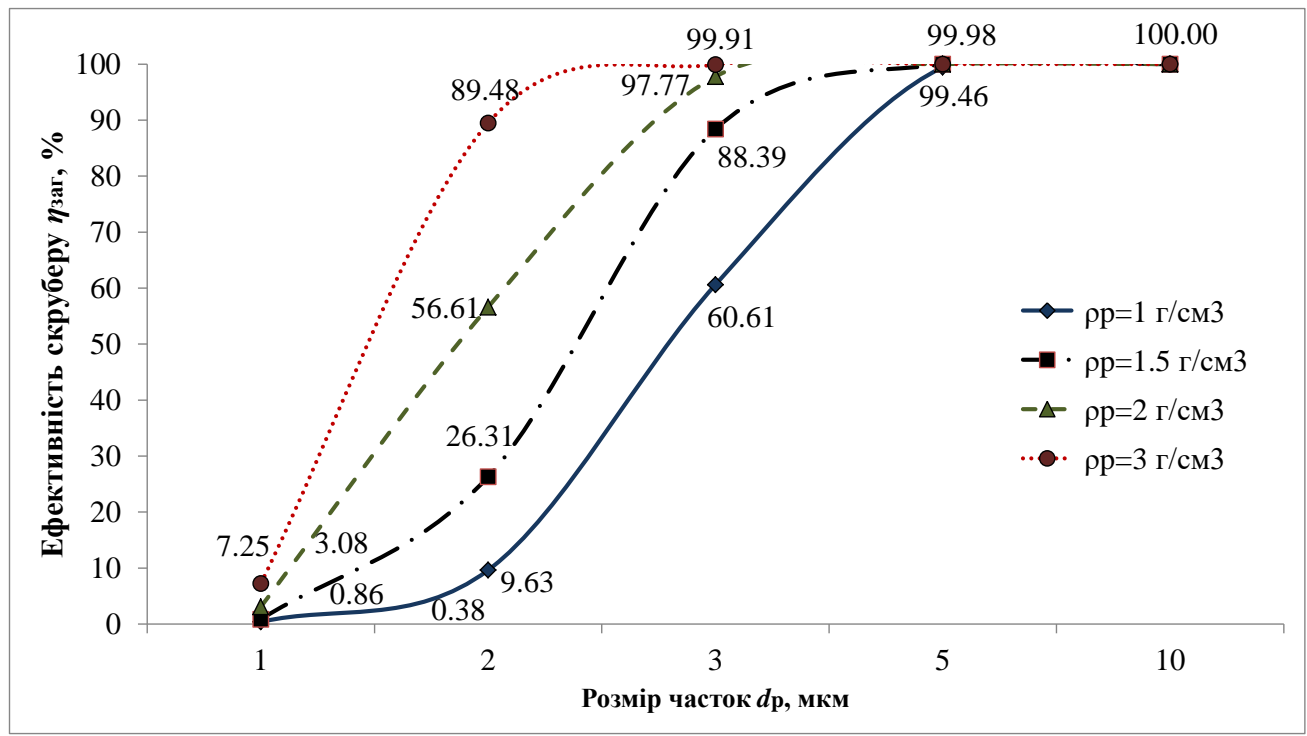

Рис. 5. Фракційна ефективність скрубера залежно від щільності часток 
де $S$ - площа перетину димової труби, м²; $D$ - діаметр гирла димової труби, м; $v$ - швидкість руху газової суміші, м/с.

Якщо припустити, що $\mathrm{Q}_{\llcorner} / \mathrm{Q}_{G}=1$ л/ $\mathrm{M}^{3}$ буде достатнім обсягом зрошувальної рідини для задовільної очистки газів від пилу, тоді обсяги утворення стічних промивних $Q_{\text {ст }}$ вод становлять:

$$
\mathrm{Q}_{\text {ст }}=\mathrm{Q}_{\mathrm{L}} / \mathrm{Q}_{G} \cdot \mathrm{V}_{\text {г }} \cdot \mathrm{t}_{\text {год }}=1 \mathrm{л} / \mathrm{M}^{3} \cdot 6,18 \mathrm{~m}^{3} / \mathrm{c} \cdot 3600 \mathrm{c} / \text { год }=
$$

3 урахуванням фракційної ефективності скрубера залежно від витрат зрошувальної рідини та щільності часток можна припустити, що максимальне уловлювання дрібнодисперсного пилу можливе для фракцій $d_{p} \geq 5$ мкм.

\section{ВИСНОВКИ}

Отримані результати дослідження дають змогу зробити такі висновки.

1. Виконано розрахунок фракційної ефективності аерозольного скрубера. Встановлено, що порожнистий скрубер вловлює дрібнодисперсні частки пилу розміром більше 5 мкм, а частки 3 мкм становлять критичний розмір для таких технологічних умов.

2. Виконано прогнозну оцінку ефективності впровадження порожнистого скрубера в технологію очистки димових газів шахтної котельні залежно від витрат зрошувальної рідини та щільності часток пилу.

Для технологічних умов котельні шахти «Україна» достатні витрати зрошувальної рідини для задовільної очистки газів від пилу становитимуть $\mathrm{Q}_{\mathrm{L}} / \mathrm{Q}_{\mathrm{G}}=1 л / \mathrm{M}^{3}$ 3 утворенням стічних вод $Q_{\text {ст }}=22,25 \mathrm{M}^{3} /$ год.

Встановлено, що уловлювання пилу зростає із щільністю пилу. 3 огляду на те, що щільність пилу

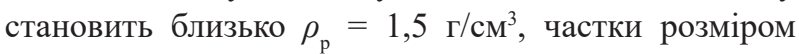
5 мкм уловлюються 3 ефективністю $\eta_{\text {заг }}=99,98 \%$, а для часток 3 мкм $\eta_{\text {заг }}=88,39 \%$ відповідно.

3 урахуванням фракційної ефективності скрубера залежно від витрат зрошувальної рідини та щільності часток можна припустити, що максимальне уловлювання дрібнодисперсного пилу можливе для фракцій $d_{p} \geq 5$ мкм.

\section{REFERENCES}

[1] Tailasheva, T. S., Krasilnikova, L. G., Vorontsova, E. S. (2013). Ocenka vrednykh vybrosov v atmosferu ot kotelnykh Tomskoi oblasti [Estimation of harmful atmospheric emissions from boiler houses in the Tomsk Region]. Bulletin of Tomsk Polytechnic University, Vol. 322, No. 4, pp.52-55.

[2] Derkachevskaya, L. B. (2013). Voprosy ekologii pri proektirovanii i rekonstrukcii shakht [Environmental issues in the design and reconstruction of mines]. Ugol Ukrainy, No. 11, pp. 35-36.

[3] Szkarowski, A., Janta-Lipińska, S., Gawin, R. (2016). Reducing emissions of nitrogen oxides from DKVR boilers. Rocznik Ochrona Srodowiska 18(1):565-578.

[4] Janta-Lipińska, S., Szkarowski, A. (2018). The study on decreasing of nitrogen oxides emission carried out on DKVR 10-13 industrial heating boilers. 10th Conference on Interdisciplinary Problems in Environmental Protection and Engineering EKODOK 2018, E3S Web of Conferences, Volume 44. P. 1-8. Retrieved from: https://doi.org/10.1051/e3sconf/20184400056.

[5] Navrodska, R., Fialko, N., Presich, G., Gnedash, G., Alioshko, S., Shevcuk, S. (2019). Reducing nitrogen oxide emissions in boilers at moistening of blowing air in heat recovery systems. 11th Conference on Interdisciplinary Problems in Environmental Protection and Engineering EKO-DOK 2019. E3S Web of Conferences 100, 000. P 1-7. Retrieved from: https://doi.org/10.1051/e3sconf/201910000055.

[6] Nimmo, W., Patsias, A. A., Hampartsoumian, E., Gibbs, B. M., Williams, P. T. (2004). Simultaneous reduction of $\mathrm{NO}_{x}$ and $\mathrm{SO}_{2}$ emissions from coal combustion by calcium magnesium acetate. Fuel, Volume 83, Issue 2, January 2004, pp. 149-155. Retrieved from: https://doi.org/10.1016/S0016-2361(03)00257-6.

[7] Apostoliuk, S. O., Dzhigirey, V. S. (2012). Promislova ekologiya [Industrial Ecology], $2^{\text {nd }}$ ed., Kyiv [in Ukrainian].

[8] Birger, M. I., Valdberg, A. Yu., Myagkov, B. I. (1975). Spravochnik po pyle- I zoloulavlivaniyu [Dust and ash collection guide]. Moscow: Energiya [in Russian].

[9] Aliiev, G. M. (1986). Tekhnika pileulavlivaniya i ochistki promyshlennykh gazov [Dust collection and purification technology for industrial gases]. Moscow: Metallurgiya [In Russian].

[10]. Cooper, C. D. Air Pollution Control: A Design Approach. / C. D. Cooper, F. C. Alley. Illinois: Waveland Press, Inc., Prospect Heights, 2011. 839 p.

\section{СПИСОК ВИКОРИСТАНОЇ ЛІТЕРАТУРИ}

[1] Тайлашева, Т. С., Красильникова, Л. Г., Воронцова, Е. С. (2013). Оценка вредных выбросов в атмосферу от котельных Томской области. Известия Томского политехнического университета. Т. 322. № 4. С.52-55.

[2] Деркачевская, Л.В.(2013). Вопросы экологии при проектировании и реконструкции шахт. Уголь Украины. № 11. С. 35-36.

[3] Szkarowski, A., Janta-Lipińska, S., Gawin, R. (2016). Reducing emissions of nitrogen oxides from DKVR boilers. Rocznik Ochrona Srodowiska, 2016. 18(1):565-578.

[4] Janta-Lipińska, S., Szkarowski, A. (2018). The study on decreasing of nitrogen oxides emission carried out on DKVR 10-13 industrial heating boilers. 10th Conference on Interdisciplinary Problems in Environmental Protection and Engineering EKO-DOK 2018, E3S Web of Conferences, Volume 44. P. 1-8. URL: https://doi.org/10.1051/e3sconf/20184400056.

[5] Navrodska, R., Fialko, N., Presich, G., Gnedash, G., Alioshko, S., Shevcuk, S. (2019). Reducing nitrogen oxide emissions in boilers at moistening of blowing air in heat recovery systems. 11th Conference on Interdisciplinary Problems in 


\section{ТЕХНОЛОГІЇ ЗАХИСТУ НАВКОЛИШНЬОГО СЕРЕДОВИЩА №1 12020}

Environmental Protection and Engineering EKO-DOK 2019. E3S Web of Conferences 100, 000. P 1-7. URL: https://doi. org/10.1051/e3sconf/201910000055.

[6] Nimmo, W., Patsias, A. A., Hampartsoumian, E., Gibbs, B. M., Williams, P. T. (2004). Simultaneous reduction of NOx and $\mathrm{SO}_{2}$ emissions from coal combustion by calcium magnesium acetate. Fuel, Volume 83, Issue 2, January. Pages 149-155. URL: https://doi.org/10.1016/S0016-2361(03)00257-6.

[7] Апостолюк, С. О., Джигирей В. С. (2012). Промислова екологія, 2-ге вид., випр, і допов. Київ, 430 с.

[8] Справочник по пыле- и золоулавливанию (1975). / М. И. Биргер, А. Ю. Вальдберг, Б. И. Мягков и др.; Под. ред. А. А. Русанова. Москва : Энергия, 296 с.

[9] Алиев, Г. М. (1986). Техника пылеулавливания и очистки промышленных газов. Москва : Металлургия, 544 с.

[10] Cooper, C. D. (2011). Air Pollution Control: A Design Approach. / C. D. Cooper, F. C. Alley. Illinois : Waveland Press, Inc., Prospect Heights. 839 p.

(C) О. С. Ковров, Д. В. Кулікова, 3. Л. Сушко Дата надходження статті до редакції: 26.03.2020 Дата затвердження статті до друку: 17.04.2020 